\title{
AYAT AL-QUR'AN DAN HADIS NABI TENTANG PRINSIP PENYAMPAIAN PELAJARAN SESUAI KEMAMPUAN SISWA
}

\author{
Aat Hidayat \\ STAIN Kudus, Jawa Tengah, Indonesia \\ aathiedayat@gmail.com
}

\begin{abstract}
AL-QUR'AN VERSES AND PROPHET HADITH OF DELIVERING LESSON PRINCIPLE IN ACCORDANCE WITH STUDENTS' ABILITY. SCL (SCL) approach appears to make the learning implementation with conducive fun atmosphere, and students centered. In the SCL approach, the teacher gives many attentions in involvement, initiative, and student social interaction in classroom. One of the principle in SCL approach is teacher delivers the lessons in accordance with students' ability. By using Fazlur Rahman double movement theory to analyze the Qur'an verses and historical criticism, eidetic criticism, and pratical criticism of Hassan Hanafi to analyze the prophet hadith, this study aims to reveal the moral ideal of Qur'an and prophet hadith about delivering lesson principle in accordance with students' ability as well as determining the contextual meaning for life recently. There are 21 Qur'an verses which contains the basic idea of delivering lesson principle in accordance with students' ability and there are 11 Hadiths which contains delivering lesson principle in accordance with students' ability. The verse and hadith show the necessity principles to put human in accordance with his position and necessity to talk with them in accordance with his ability, and completed with practical examples from the Prophet. The implementation of educational values in some Qur'an verses and
\end{abstract}


Prophet hadith is able to make the learning more empower the students' potential and influence on student personality development.

Keywords: SCL, Learning, Students'Ability.

\begin{abstract}
Abstrak
Pendekatan SCL (SCL) muncul untuk mewujudkan terlaksananya pembelajaran dengan suasana yang kondusif, menyenangkan, dan berpusat pada siswa. Dalam pendekatan SCL, guru banyak memberikan perhatian pada keterlibatan, inisiatif, dan interaksi sosial siswa di kelas. Salah satu prinsip yang ada dalam pendekatan SCL adalah guru menyampaikan pelajaran sesuai kemampuan siswa. Dengan menggunakan teori double movement Fąlur Rabman untuk menganalisis ayat Al-Qur'an serta kritik historis, kritik eidetis, dan kritik praksis Hassan Hanafi untuk menganalisis hadis Nabi, tulisan ini bermaksud mengungkap ideal moral ayat Al-Qur'an dan hadis Nabi tentang prinsip penyampaian pelajaran sesuai kemampuan siswa serta menentukan makna kontekstualnya bagi kehidupan saat ini. Ada 21 ayat Al-Qur'an yang mengandung ide dasar prinsip penyampaian pelajaran sesuai kemampuan siswa dan ada 11 hadis yang mengandung prinsip penyampaian pelajaran sesuai kemampuan siswa. Ayat dan hadis tersebut menampilkan prinsip keharusan menempatkan manusia sesuai kedudukannya serta kemestian berbicara dengan mereka sesuai dengan kemampuannya, juga disertai contoh praksis dari Rasulullah saw. Implementasi nilai-nilai edukatif dalam beberapa ayat Al-Qur'an dan hadis Nabi ini mampu mewujudkan pembelajaran yang lebih memberdayakan potensi anak didik serta berpengaruh pada pengembangan kepribadian siswa.
\end{abstract}

Kata Kunci: SCL, Pembelajaran, Kemampuan Siswa.

\title{
A. Pendahuluan
}

Seiring dengan perkembangan zaman, dunia pembelajaran mengalami perkembangan. Banyak teori yang merupakan ekses positif dari perkembangan kehidupan terhadap dunia pendidikan dan pembelajaran. Di antaranya adalah teori Contectual Teaching and 
Ayat Al-Qur'an Dan Hadis Nabi Tentang...

Learning (CTL), teori Quantum Learning, teori Quantum Teaching, dan teori Multiple Intelligences. ${ }^{1}$

Mengikuti perkembangan teori pembelajaran sebagaimana dipaparkan di atas, pendekatan dalam proses pembelajaran ${ }^{2}$ pun mengalami perubahan dan perkembangan. Yakni, pembelajaran yang tadinya berpusat pada guru SCL menjadi pembelajaran yang berpusat pada siswa SCL. Pembelajaran yang berpusat pada siswa SCL ini diharapkan dapat mendorong siswa untuk terlibat secara lebih aktif dalam membangun pengetahuan, sikap, dan perilaku mereka. $^{3}$

Secara definitif, pembelajaran yang berpusat pada siswa SCL adalah pembelajaran dengan menggunakan sepasang perspektif, yaitu fokus pada individu pembelajar (keturunan, pengalaman, perspektif, latar belakang, bakat, minat, kapasitas, dan kebutuhan) dan fokus pada pembelajaran (pengetahuan yang paling baik tentang pembelajaran serta tentang praktik pengajaran yang paling efektif dalam meningkatkan tingkat motivasi, pembelajaran, dan prestasi bagi semua pembelajar). Fokus ganda ini selanjutnya memberikan informasi dan dorongan pengambilan keputusan pendidikan. Ringkasnya, SCL merupakan pendekatan pembelajaran yang lebih berfokus pada kebutuhan siswa, bukan berfokus pada pihak-pihak yang terlibat dalam proses pembelajaran, seperti pengajar dan administrator. ${ }^{4}$

${ }^{1}$ Penjelasan mengenai perkembangan baru pembelajaran, lihat Yatim Riyanto, Paradigma Baru Pembelajaran: Sebagai Referensi bagi Pendidik dalam Implementasi Pembelajaran yang Efektif dan Berkualitas (Jakarta: Kencana, 2010).

${ }^{2}$ Wina Sanjaya mengartikan pendekatan pembelajaran sebagai titik tolak atau sudut pandang terhadap proses pembelajaran. Wina Sanjaya, Strategi Pembelajaran Berorientasi Standar Proses Pendidikan (Jakarta: Kencana, 2010), hlm. 127.

${ }^{3}$ Tentang perubahan paradigma ini, baca Rahmini Hadi, "Dari TeacherCentered Learning ke SCL: Perubahan Metode Pembelajaran di Perguruan Tinggi”, dalam Jurnal Insania, Vol. 12, No. 3, September-Desember 2007, hlm. 1-8; Harsono, "Kearifan dalam Transformasi Pembelajaran: dari Teacher-Centered Learning ke SCL", dalam wnm.inparametric.com, 10 April 2015; Tina Afiatin, "Pembelajaran Berbasis SCL", dalam www.inparametric.com, 10 April 2015.

"Yanti D.P., "SCL", dalam www.bintangbangsaku.com, 10 April 2015. 
Sebenarnya pendekatan pembelajaran yang berbasis pada siswa SCL berabad yang lalu telah dicontohkan dan dipraktikkan oleh Rasulullah saw. Memang tidak sepenuhnya pendekatan pembelajaran SCL ini sesuai dengan pendekatan yang dicontohkan oleh Rasulullah saw. Akan tetapi, dengan melihat salah satu prinsip pendekatan pembelajaran SCL, yakni pengajar menggunakan cara penyampaian materi yang dianggap sesuai dengan kebutuhan dan kondisi siswa, atau dengan kata lain guru menyampaikan pelajaran sesuai dengan kemampuan siswa, pendekatan pembelajaran yang dilakukan oleh Rasulullah saw. terhadap para sahabatnya memiliki keserasian. Letak perbedaan yang ada mungkin disebabkan oleh adanya inovasi dan pengembangan, tetapi dalam prinsip memiliki persamaan.

Dalam artikel ini, penulis hanya akan melihat salah satu prinsip yang ada dalam pendekatan SCL, yakni guru menyampaikan pelajaran sesuai dengan kemampuan siswa. Dengan demikian, artikel ini diarahkan pada penelusuran ayat Al-Qur'an dan hadis Nabi yang menggambarkan pendekatan pembelajaran Rasulullah saw. yang memerhatikan kondisi dan kompetensi siswa. Selanjutnya penulis akan melakukan pemaknaan dan kontekstualisasi terhadap beberapa ayat Al-Qur'an dan hadis Nabi tersebut.

\section{B. Pembahasan}

\section{Teori Konstruktivisme Sebagai Landasan}

Titik pijak yang menjadi landasan perubahan paradigma pembelajaran adalah teori konstruktivisme, sebagai kebalikan dari teori positivistik. Dalam teori positivistik, pembelajaran dilakukan dengan pendekatan yang bersifat memaksa sehingga menciptakan suasana pembelajaran yang tidak nyaman, menimbulkan rasa takut, dan bahkan bisa membuat siswa stres. Sementara, dalam teori konstruktivisme, pembelajaran dilakukan 
dalam suasana yang kondusif dan menyenangkan. ${ }^{5}$ Awalnya teori konstruktivisme ini merupakan satu konsep pembelajaran yang banyak membicarakan masalah pembelajaran dan diharapkan mampu menjadi landasan intelektual untuk menyusun dan menganalisis problem pembelajaran dalam pergulatan di dunia pendidikan, khususnya dalam menghadapi tantangan dan perubahan zaman. ${ }^{6}$

Secara etimologis, konstruktif berarti bersifat membangun. Dalam konteks filsafat pendidikan, konstruktivisme merupakan suatu aliran yang berupaya membangun tata susunan hidup kebudayaan yang bercorak modern. Lebih lanjut dikemukakan oleh Jalaluddin Rakhmat, sebagaimana dikutip oleh Yatim Riyanto, teori konstruktivisme berupaya membina suatu konsensus yang paling luas dan mengenai tujuan pokok dan tertinggi dalam kehidupan umat manusia. ${ }^{7}$

Sebagaimana dikemukakan oleh Yatim Riyanto dengan mengutip penjelasan R. Wilis Dahar, sebagai sebuah filsafat pembelajaran, teori konstruktivisme pertama kali terdapat dalam tulisan seorang filusuf yang bernama Giambattista Vico pada tahun 1710. Dalam tulisan tersebut, Vico mengemukakan bahwa seseorang hanya dapat benar-benar memahami sesuatu yang dikonstruksinya atau dibangunnya sendiri. Banyak yang sepaham dan mendukung gagasan ini. Akan tetapi, pengembangan teori ini yang lebih lanjut diaplikasikan dalam dunia pembelajaran dan perkembangan anak adalah Jean Piaget. $^{8}$

Pandangan konstruktivisme menyatakan bahwa pengetahuan dibangun dalam pikiran seseorang. Pandangan ini meng-counter pandangan klasik yang selama ini berkembang yang menyatakan bahwa pengetahuan secara utuh dipindahkan

${ }^{5}$ Hamruni, Edutainment dalam Pendidikan Islam dan Teori-teori Pembelajaran Quantum (Yogyakarta: Fakultas Tarbiyah UIN Sunan Kalijaga Yogyakarta, 2009), hlm. 6-7.

\footnotetext{
${ }^{6}$ Yatim Riyanto, Paradigma Baru Pembelajaran, hlm. 143.

${ }^{7}$ Ibid.

${ }^{8}$ Ibid., hlm. 143-144.
} 
dari pikiran guru (sebagai sebuah teko yang berisi air) ke dalam pikiran siswa (sebagai sebuah gelas kosong yang harus diisi air). Dari sini bisa ditarik pemahaman bahwa tujuan pembelajaran konstruktivistik ditekankan pada "proses" pembelajaran, yakni bagaimana menciptakan pemahaman baru yang menuntut aktivitas kreatif produktif dalam konteks nyata yang mendorong seorang pembelajar (siswa) untuk terus berpikir dan mendayagunakan kemampuannya yang kemudian diikuti dengan proses mendemonstrasikan hasil dari pemikiran tersebut. ${ }^{9}$

Dalam upaya mencapai tujuan tersebut, teori konstruktivisme berupaya mencari kesepakatan di antara sesama manusia, yakni agar dapat mengatur tata kehidupan manusia dalam suatu tatanan dan seluruh lingkungannya. Teori ini bertolak belakang dengan teori belajar konvensional yang sama sekali tidak memberikan ruang gerak kepada siswa untuk berpikir dan berkreasi. Maka, proses pembelajaran dalam teori konstruktivisme menghendaki adanya proses membangun kemandirian anak didik untuk mengelola pola pikir secara terarah. Konsep pembelajaran dalam teori konstruktivisme menghendaki agar anak didik dapat dibandingkan kemampuannya untuk secara konstruktif menyesuaikan diri dengan tuntutan ilmu pengetahuan dan teknoligi. Dengan demikian, menurut Imam Bernadib, sebagaimana dikutip oleh Yatim Riyanto, anak didik akan tetap berada dalam suasana yang aman dan bebas, bahkan menyenangkan. ${ }^{10}$

Selanjutnya, menurut teori pembelajaran konstruktivisme, peran seorang guru adalah menyediakan suasana di mana siswa dapat belajar lebih banyak. Dengan demikian, dalam kegiatan pembelajaran, siswa harus bekerja keras untuk memecahkan masalah, menemukan segala sesuatu untuk dikonstruk menjadi ilmu dan pengetahuan bagi diri mereka, serta berusaha meramu dan memikirkan ide-ide dan pemikiran. Dalam kondisi ini,

\footnotetext{
${ }^{9}$ Ibid., hlm. 144.

${ }^{10}$ Ibid.
} 
tugas guru hanya mengarahkan kegiatan belajar siswa, bukan menjadikan siswa benar-benar memahami dan menerapkan pengetahuan yang disampaikannya. ${ }^{11}$

Satu prinsip penting yang terdapat dalam teori psikologi pendidikan menyatakan bahwa seorang guru tidak sekadar memberikan dan menyampaikan pengetahuan kepada siswa, tetapi siswa dituntut untuk mampu membangun sendiri pengetahuan yang dibutuhkannya. Dalam hal ini, guru harus memberikan kesempatan kepada siswa untuk menentukan dan menerapkan ide-ide mereka sendiri untuk belajar. Sebagai perumpamaan, guru hanya memberikan anak tangga kepada siswa yang akan mengantarkan siswa pada pemahaman yang lebih tinggi, tetapi dengan catatan siswa sendiri harus memanjat anak tangga tersebut dengan sekuat tenaga dan dengan segenap kemampuan yang dimiliki. ${ }^{12}$

Dengan demikian, pendekatan konstruktivistik dalam pengajaran lebih menekankan pada pengajaran botton up (dari bawah ke atas, kreativitas siswa yang difasilitasi oleh guru) daripada top down (dari atas ke bawah, instruksi guru yang harus diterima mentah-mentah oleh siswa). ${ }^{13}$ Artinya, siswa memulai pembelajaran dengan masalah kompleks yang dihadapinya seharihari untuk kemudian dipecahkan dan dicari solusinya secara bersama. Dari proses ini, dengan bimbingan seorang guru yang kreatif dan inovatif, siswa akan menemukan solusi, keterampilan baru, bahkan ilmu pengetahuan orisinal yang kelak dapat menjadi bekal mereka dalam menghadapi kehidupan.

Kesimpulannya, bangunan pemahaman sekaligus penataan perilaku anak didik menjadi titik perhatian dalam teori pembelajaran konstruktivisme. Praktik pembelajaran konstruktif dilakukan untuk membantu siswa dalam membentuk dan

\footnotetext{
${ }^{11}$ Ibid., hlm. 144-145.

${ }^{12}$ Ibid., hlm. 144.

${ }^{13} \mathrm{Ibid}$.
} 
mengubah diri serta mentransformasikan informasi baru dalam permasalahan riil yang dihadapi oleh mereka. ${ }^{14}$

Secara ringkas, ada lima prinsip dasar teori konstruktivisme dalam pembelajaran, yaitu menghadapi masalah yang relevan dengan siswa, struktur pembelajaran seputar konsep utama pentingnya sebuah pertanyaan, mencari dan menilai pendapat siswa, menyesuaikan kurikulum untuk menanggapi anggapan siswa, dan menilai belajar siswa dalam konteks pembelajaran. ${ }^{15}$ Prinsip dasar teori konstruktivisme yang berhubungan dengan pendekatan SCL (SCL) yang menjadi tema utama dalam artikel ini adalah prinsip menyesuaikan kurikulum untuk menanggapi anggapan siswa. Asumsi dasar dari prinsip ini menyatakan bahwa belajar akan menjadi lebih baik jika tuntutan kognitif, sosial, dan emosional dari kurikulum dapat dicapai oleh para siswa. Oleh karena itu, dibutuhkan kemauan dan kemampuan para guru untuk menyesuaikan tugas-tugas kurikuler dengan anggapan (baca: kemampuan, situasi, dan kondisi) yang dimiliki oleh para siswa. Dan, tugas kurikuler akan dianggap sukses bila siswa dapat menyelesaikannya. ${ }^{16}$

\section{SCL: Pembelajaran Berpusat pada Siswa}

Undang-undang No. 20 Tahun 2003 Tentang Sistem Pendidikan Nasional Bab I Pasal 1 Ayat 1 menyatakan bahwa "yang dimaksud dengan pendidikan adalah usaha sadar dan terencana mewujudkan suasana belajar dan proses pembelajaran agar peserta didik secara aktif mengembangkan potensinya sendiri”. Pernyataan ini lantas dipertegas dalam Bab II Pasal 3, "Pendidikan nasional bertujuan untuk mengembangkan potensi peserta didik agar menjadi manusia yang beriman dan bertakwa kepada Tuhan Yang Maha Esa, berakhlak mulia, sehat, berilmu,

\footnotetext{
${ }^{14}$ Ibid.

${ }^{15}$ Ibid., hlm. 147-151.

${ }^{16}$ Ibid., hlm. 149-150.
} 
cakap, kreatif, mandiri, dan menjadi warga negara yang demokratis serta bertanggung jawab." ${ }^{\prime 17}$

Dua pasal dari Undang-undang Sistem Pendidikan Nasional (UU Sisdiknas) inilah yang menjadi landasan bagi diterapkannya pendekatan pembelajaran yang berpusat pada siswa atau biasa dikenal dengan istilah SCL. Dari dua pasal utama yang melandasai pendekatan pembelajaran yang berpusat pada siswa tersebut terdapat suatu perubahan mendasar, yakni perubahan paradigma dari pengajaran menjadi pembelajaran. Dalam pengajaran, peranan guru di kelas lebih dominan daripada siswa. Dalam paradigma ini, siswa hanyalah merupakan gelas kosong yang terus-menerus diisi pengetahuan secara pasif oleh guru. Sementara, dalam paradigma pembelajaran, justru siswalah yang berperan aktif sekaligus mengoreksi peranan dominan guru. ${ }^{18}$

Konsep ini dipertegas lagi oleh penjelasan Peraturan Pemerintah Republik Indonesia No. 19 Tahun 2005 Tentang Standar Nasional Pendidikan yang menyatakan bahwa visi pendidikan dalam UU Sisdiknas No. 20 Tahun 2003 merupakan perubahan paradigma pendidikan dari paradigma pengajaran bergeser menjadi paradigma pembelajaran. ${ }^{19}$ Jadi, istilah pengajaran dan pembelajaran tidak semata istilah teknis, tetapi satu istilah yang di dalamnya memangku perubahan paradigma. Dan, di dalam perubahan paradigma tersebut terselubung perdebatan sengit antara ideologi pendidikan konservatif dengan ideologi pendidikan progresif. Secara lebih rinci, Peraturan Pemerintah Republik Indonesia No. 19 Tahun 2005 Pasal 19 menyatakan bahwa "proses pembelajaran pada satuan pendidikan diselenggarakan secara interaktif, inspiratif, menyenangkan,

${ }^{17}$ Undang-undang No. 20 Tahun 2003 Tentang Sistem Pendidikan Nasional.

${ }^{18}$ Utomo Dananjaya, Media Pembelajaran Aktif (Bandung: Penerbit Nuansa bekerja sama dengan Institute for Education Reform [IER] Universitas Paramadina, 2010), hlm. 25.

${ }^{19}$ Peraturan Pemerintah Republik Indonesia No. 19 Tahun 2005 Tentang Standar Nasional Pendidikan. 
menantang, memotivasi peserta didik untuk berpartisipasi aktif, serta memberikan ruang yang cukup bagi prakarsa, kreativitas, dan kemandirian sesuai dengan bakat, minat, dan pengembangan fisik serta psikologi peserta didik". ${ }^{20}$

Lebih jauh, dua pasal fundamental dari UU Sisdiknas yang melandasi perubahan dari pengajaran yang berpusat pada guru menjadi pembelajaran yang berpusat pada siswa di atas memiliki payung hukum di atasnya. Payung hukum tersebut adalah Pasal 31 Undang-undang Dasar 1945 tentang pendidikan yang selanjutnya mengalami amandeman. Dan, UU Sisdiknas berfungsi sebagai hukum dasar, visi dan misi, serta pilihan ideologis pendidikan nasional bangsa Indonesia. Dalam praktik di kelas, visi dan misi yang tersirat dalam UU Sisdiknas tersebut diimplementasikan dengan menerapkan pendekatan pembelajaran SCL atau pembelajaran yang berpusat pada siswa. ${ }^{21}$

Lantas apa urgensi pembelajaran yang berpusat pada siswa dalam penyelenggaraan pendidikan? Dengan adanya perubahan paradigma pendidikan dari pengajaran yang berpusat pada guru (teacher-centered learning atau lecture-centered learning) menjadi pembelajaran yang berpusat pada siswa SCL diharapkan proses pembelajaran akan lebih efektif dalam mewujudkan pendidikan yang demokratis, berkeadilan, tidak diskriminatif, dan menjunjung tinggi nilai-nilai hak asasi manusia, nilai-nilai agama, nilai-nilai budaya, serta kemajemukan bangsa. ${ }^{22}$ Inilah urgensi pendekatan SCL dalam pembelajaran di tengah suasana pembelajaran yang makin jauh dari esensi membangun karakter dan kepribadian siswa. ${ }^{23}$

\footnotetext{
${ }^{20}$ Utomo Dananjaya, Media Pembelajaran Aktif, hlm. 25 dan 30.

${ }^{21}$ Ibid., hlm. 26.

${ }^{22}$ Ibid., hlm. 27.

${ }^{23}$ Tentang hal ini, Marjohan menjelaskan bahwa daya tarik sekolah dan kualitas lulusannya mengalami kemerosotan. Salah satu buktinya adalah pelaksanaan disiplin yang macet dan masih suburnya rasa malas yang bercokol dalam diri banyak orang. Menurut Marjohan, kondisi sekolah dan kualitas lulusannya yang mengecewakan ini diakibatkan oleh masih bertahannya gaya
} 
Hal ini juga ditegaskan oleh Abuddin Nata yang menyatakan bahwa pembelajaran yang berpusat pada aktivitas peserta didik (student centris) mengondisikan kelas dalam suasana yang lebih demokratis, adil, manusiawi, memberdayakan, menyenangkan, menggairahkan, menggembirakan, mem-bangkitkan minat belajar, merangsang timbulnya inspirasi, imajinasi, kreasi, inovasi, etos kerja, dan semangat hidup. Dengan cara ini, maka seluruh potensi manusia dapat tergali dan teraktualisasikan dalam kehidupan yang pada gilirannya dapat menolong dirinya untuk menghadapi berbagai tantangan hidup di era modern yang penuh dengan persaingan. ${ }^{24}$ Inilah tujuan utama pembelajaran yang diisyaratkan dalam Peraturan Pemerintah Republik Indonesia No. 19 Tahun 2005 Bab IV Pasal 19. Dan, di sinilah letak urgensi pembelajaran yang berpusat pada siswa, yakni mewujudkan tujuan utama pembelajaran sebagaimana tersurat dalam Peraturan Pemerintah Republik Indonesia No. 19 Tahun 2005 Bab IV Pasal 19 di ruang-ruang kelas.

SCL (SCL) merupakan buah dari inovasi para pemikirpembaru di bidang pendidikan semisal John Dewey, Jean Piaget, dan Lev Vygotsky. Dalam pembelajaran yang menggunakan pendekatan SCL, siswa ditempatkan sebagai pusat dari kegiatan belajar. Konsep ini dilandasi oleh salah satu penelitian mengenai kerja otak manusia yang menyebutkan bahwa siswa belajar secara lebih baik dengan cara mengalami langsung dan mengontrol proses belajar tersebut. ${ }^{25}$

Dalam pendekatan SCL, pembelajar memiliki tanggung jawab penuh atas kegiatan belajarnya, terutama dalam bentuk keterlibatan aktif dan partisipasif siswa. Hubungan antara siswa

mengajar konvensional yang masih bersifat text book. Marjohan, School Healing: Menyembubkan Problem Sekolah (Yogyakarta: Insan Madani, 2009), hlm. 18-19.

${ }^{24}$ Abuddin Nata, Perspektif Islam Tentang Strategi Pembelajaran (Jakarta: Kencana, 2009), hlm. 3.

${ }^{25}$ Endang Nugraheni, "Student Centered Learning dan Implikasinya terhadap Proses Pembelajaran", dalam Jurnal Pendidikan, Volume 8, Nomor 1, Maret 2007, hlm. 1-2. 
yang satu dengan yang lainnya adalah setara, yakni tercermin dalam bentuk kerja sama dalam kelompok untuk menyelesaikan suatu tugas belajar. Guru lebih berperan sebagai fasilitator yang mendorong perkembangan siswa, dan bukan merupakan satu-satunya sumber belajar. Keaktifan siswa telah dilibatkan sejak awal dalam bentuk desain belajar yang memperhitungkan pengetahuan, keterampilan, dan pengalaman belajar siswa yang telah didapatkan sebelumnya. Dari pengalaman praktik yang ada, diharapkan setelah mengalami pembelajaran dengan pendekatan SCL, siswa akan melihat dirinya secara berbeda, dalam arti lebih memahami manfaat belajar, lebih dapat menerapkan pengetahuan dan keterampilan yang dipelajari, serta lebih percaya diri. ${ }^{26}$

\section{Ayat Al-Qur'an Tentang Prinsip Penyampaian Pelajaran Sesuai Kemampuan Siswa}

Adapun sejumlah ayat Al-Qur'an yang secara tersirat menjadi landasan normatif bagi pelaksanaan pendekatan SCL dalam pembelajaran, terutama yang terkait dengan prinsip penyampaian pelajaran sesuai kemampuan siswa, adalah Q.S. Ibrahim [14]: 4, Q.S. Yasin [36]: 17, dan Q.S. Fushshilat [41]: 44. Penentuan ayat-ayat Al-Qur'an ini sebagai landasan normatif bagi pendekatan SCL penulis lakukan melalui penelusuran tematik dengan bantuan Klasifikasi Ayat-ayat Al-Qur'an yang terdapat dalam Al-Qur'an Tajwid dan Terjemahnya Syämil Al-Qur'an. Ayatayat ini terdapat dalam Bab "Dakwah" pada bagian "dakwah harus dengan bahasa yang dipahami”. ${ }^{27}$

Dari tiga ayat tersebut, ada tiga istilah kunci yang bisa digunakan untuk mengidentifikasi salah satu prinsip pendekatan SCL, yakni penyampaian pelajaran sesuai kemampuan siswa,

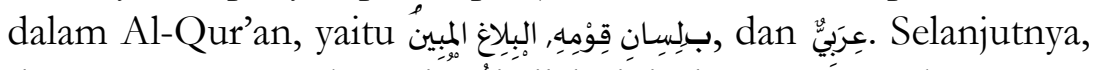
dengan menggunakan tiga 'istilah ini dan turúnan kata yang

${ }^{26}$ Ibid.

${ }^{27}$ Kementerian Agama RI, Al-Qur'an Tajwid dan Terjemabnya Syāmil AlQur'an (Bandung: Sygma Examedia Arkanleema, 2010), hlm. 14. 
berdekatan dengannya, penulis melakukan penelusuran lanjutan terhadap ayat-ayat sejenis dengan menggunakan al-Mu'jam alMufahras li Alfäa. Al-Qur'an Al-Kärim karya Muhammad Fu'ad Abd al-Baqi. Hasilnya, ada 19 ayat lain selain 3 ayat di atas yang secara tersirat menggambarkan pendekatan pembelajaran yang berpusat pada siswa (pendekatan SCL). Rinciannya sebagai berikut.

a. Kata بلسَان قَوْمه (Q.S. Ibrahim [14]: 4) dan kata turunannya terdapát júga đalam Q.S. al-Nahl [16]: 103, Q.S. Maryam [19]: 97, Q.S. al-Syu'ara' [26]: 13 dan 195, Q.S. al-Qashash [28]: 34, Q.S. al-Dukhan [44]: 58, dan Q.S. al-Ahqaf [46]: $12 .^{28}$

b. Kata الْبََاغُ المْبِينُ (Q.S. Yasin [36]: 17) terdapat juga dalam Q.S. al-Ma'idah [5]: 92, Q.S. al-Nahl [16]: 82, Q.S. al-Nur [24]: 54, Q.S. al-Ankabut [29]: 18, dan Q.S. al-Tagabun [64]: $12 .^{29}$

c. Kata عِرَبِي (Q.S. Fushshilat [41]: 44) dan kata turunannya terdapat juga dalam Q.S. Yusuf [12]: 2, Q.S. al-Ra'd [13]: 37, Q.S. al-Nahl [16]: 103, Q.S. Thaha [20]: 113, Q.S. alSyu'ara' [26]: 195, Q.S. al-Zumar [39]: 28, Q.S. Fushshilat [41]: 3, dan Q.S. al-Zukhruf [43]: 3. ${ }^{30}$

Jadi, ada sekitar 21 ayat Al-Qur'an yang secara tersirat (figuurlijk) menggambarkan pendekatan pembelajaran yang berpusat pada siswa. Walaupun secara letterlijk (tersurat) ayat-ayat tersebut tidak menjelaskan salah satu prinsip pendekatan SCL dalam pembelajaran, namun ideal moral yang terdapat dalam ayat-ayat tersebut mengarah pada prinsip penyampaian pelajaran sesuai kemampuan siswa dalam pendekatan SCL.

${ }^{28}$ Muhammad Fu'ad Abd al-Baqi, al-Mu'jam al-Mufahras li Alfaz. Al-Qur'an Al-Karim (Kairo: Dār al-Hadìis, 2007), hlm. 746.

${ }^{29}$ Ibid., hlm. 166.

${ }^{30}$ Ibid., hlm. 559-560. 


\section{Hadis Nabi Tentang Prinsip Penyampaian Pelajaran Sesuai Kemampuan Siswa}

Selain disinggung secara tersirat dalam sejumlah ayat AlQur'an, prinsip penyampaian pelajaran sesuai kemampuan siswa yang merupakan salah satu prinsip dari pendekatan SCL (SCL) juga diungkapkan secara tersirat dalam beberapa hadis Nabi. Bahkan, dalam menyampaikan risalah kepada para sahabatnya, Rasulullah saw. juga kerap melakukan pengajaran dengan mempertimbangkan aspek intelektual, sosial, dan psikologi para sahabat. Dan, inilah hakikatnya idealisme dari pendekatan SCL dalam pembelajaran.

Sebagai contoh, berikut ini adalah hadis riwayat Imam Bukhari yang menggambarkan praktik pengajaran Rasulullah saw. kepada Mu'adz bin Jabal dengan memperhatikan kondisi peserta didik.

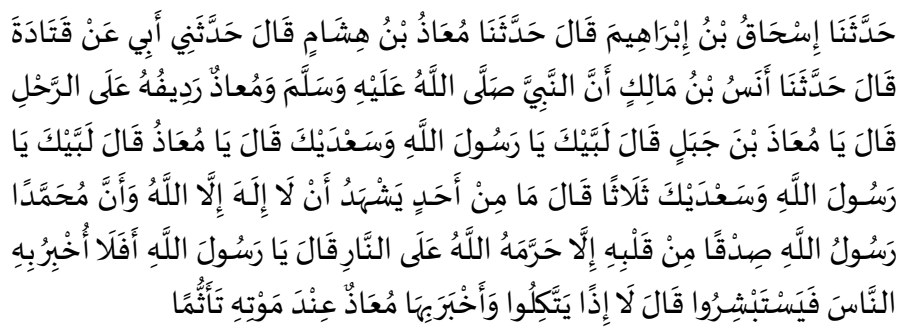

Dari Anas bin Malik, dia berkata: Nabi Muhammad saw. pernah membonceng Mu'adz bin Jabal. Pada saat itu Rasulullah saw. memanggil Mu'adz, "Wahai Mu'adz bin Jabal!" Mu'adz pun menjawab, "Aku sambut seruanmu dan aku taati perintahmu, wahai Rasulullah." Rasulullah saw. memanggil Mu'adz lagi, "Wahai Mu'adz!" Mu’adz menjawab, "Aku sambut seruanmu dan aku taati perintahmu, wahai Rasulullah." Rasulullah saw. mengulangi panggilannya sampai tiga kali. Kemudian Rasulullah saw. bersabda, "Tidak seorang hamba pun yang bersaksi dengan sungguhsungguh dari lubuk hatinya bahwa tidak ada tuhan selain Allah swt. dan Muhammad saw. adalah hamba dan rasul-Nya, kecuali Allah swt. akan mengharamkan hamba tersebut masuk neraka." Mu'adz bertanya, "Wahai Rasulullah, apakah hal ini dapat aku beri tahukan kepada manusia supaya mereka senang?" Rasulullah saw. menjawab, "Jangan, karena mereka akan enggan beramal." Akan tetapi, Mu'adz kemudian memberitahukan hal tersebut ketika menjelang ajalnya. 
Hal itu ia lakukan karena takut akan mendapatkan dosa lantaran menyembunyikan ilmu. ${ }^{31}$

Hadis di atas menggambarkan proses penahapan peserta didik dalam mempelajari ilmu pengetahuan yang dicontohkan oleh Rasulullah saw. kepada sahabat setianya, yaitu Mu'adz bin Jabal. Dalam hadis ini dikisahkan bahwa Mu'adz bin Jabal dilarang menyampaikan kabar tentang keutamaan orang yang mengucapkan dua kalimat syahadat kepada orang lain. Alasan yang diberikan oleh Rasulullah saw. adalah agar orang lain yang mendengar informasi ini tidak malas dalam beribadah. Hanya dengan mengucapkan dua kalimat syahadat saja sudah cukup menjadikan seseorang masuk surga, jadi kenapa harus bersusah payah beribadah. Akibat inilah yang dikhawatirkan oleh Rasulullah saw. akan terjadi di kalangan umatnya jika mendengar informasi tersebut. Oleh karena itu, Rasulullah saw. melarang Mu'adz bin Jabal menyampaikan informasi ini kepada orang lain. Pertanyaannya, kenapa Rasulullah saw. tetap memberitakan informasi ini kepada Mu'adz bin Jabal? Jawabannya adalah karena dalam pandangan Rasulullah saw., Mu'adz bin Jabal termasuk seorang sahabat yang teguh dan rajin dalam beribadah. Bagaimana mungkin seorang Mu'adz bin Jabal malas melakukan ibadah setelah mendengar informasi tersebut. Karena anggapan inilah Rasulullah saw. tetap memberikan informasi tersebut kepada Mu'adz bin Jabal.

Selain hadis di atas, masih banyak hadis lain yang menggambarkan pengajaran yang dilakukan oleh Rasulullah saw. sebagai pendidik kepada para sahabatnya sebagai peserta

${ }^{31}$ Hadis ini diriwayatkan oleh Imam Bukhari dari Anas bin Malik. Lihat Abu Abdullah Muhammad bin Isma'il al-Bukhari, al-Jami" as-Șạ̣iḩ, Kitab "al-Ilm”, No. 125, dalam Program Mausü'ah al-Hadisis asy-Syarif, Versi 2 (t.tp.: Global Islamic Software Company, 1997). Selain itu, hadis ini juga diriwayatkan oleh Imam Muslim dari Anas bin Malik. Lihat Abu al-Husain Muslim bin al-Hajjaj al-Qusyairi an-Naisyaburi, Șậị̆ Muslim, Kitab “al-Imān”, No. 47, dalam Program Mausū'ah alHadis asy-Syarif, Versi 2 (t.tp.: Global Islamic Software Company, 1997). 
didik dengan menggunakan prinsip penyampaian pelajaran sesuai kemampuan siswa. Selain sebagai seorang utusan Allah swt., Nabi Muhammad saw. juga berperan sebagai seorang guru (educator) dengan berbagai variasi metode dan pendekatan pembelajarannya. Inilah model pembelajaran Rasulullah saw. (Prophetic Learning) yang mesti dirumuskan dan diteladani oleh para praktisi pendidikan Islam.

Hadis yang mengandung nilai dasar salah satu prinsip pendekatan SCL (SCL), yakni prinsip penyampaian pelajaran sesuai kemampuan siswa, adalah sebuah hadis yang diriwayatkan oleh Abu Dawud dalam Kitab “al-Adab” No. 4202. Redaksi hadis dimaksud sebagai berikut.

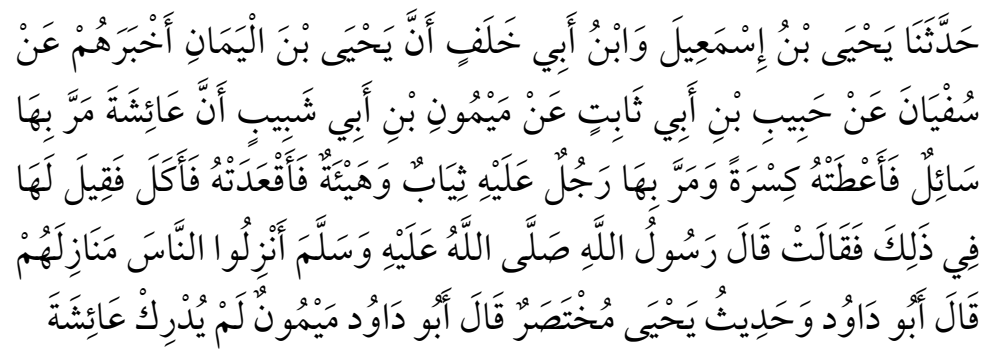

Telah menceritakan kepada kami Yahya bin Isma'il dan Ibnu Abi Khalaf, bahwa Yahya bin al-Yaman menerima kabar dari Sufyan, dari Habib bin Abi Tsabit, dari Maimun bin Abi Syabib. Telah lewat di hadapan 'Aisyah seseorang bernama Sa'il, lalu 'Aisyah memberinya pecahan roti. Dan, telah lewat pula di hadapan 'Aisyah seseorang yang mengenakan pakaian yang bagus, lalu 'Aisyah menjamu orang tersebut dan makan bersamanya. Lantas 'Aisyah ditanya mengenai tindakannya ini. 'Aisyah berkata: Rasulullah saw. bersabda, "Posisikan manusia sesuai dengan kedudukannya." 32

${ }^{32}$ Abu Dawud Sulaiman bin al-Asy'ats as-Sijistani al-Asadi, Sunan A $\overline{b i}$ Dawnd, Kitab "al-Adab”, No. 4202, dalam Program Mausü'ah al-Hadis asy-Syarif, Versi 2 (t.tp.: Global Islamic Software Company, 1997). 
Selain hadis di atas, sebenarnya ada dua asar yang menjelaskan secara tersurat hakikat prinsip penyampaian pelajaran sesuai kemampuan siswa. Asar dimaksud adalah sebagai berikut.

1) Asar yang diriwayatkan oleh Imam Bukhari dalam Kitab "al-Tlm" No. 124.

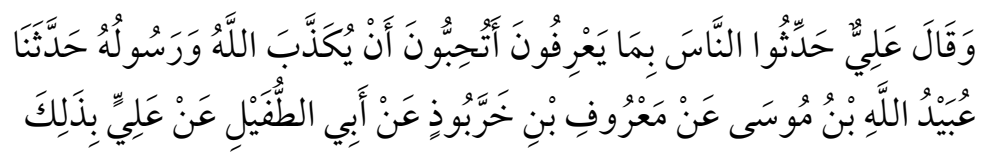

Dan, 'Ali berkata, "Berbicaralah dengan manusia sesuai dengan kadar pemahaman mereka, apakah kalian ingin jika Allah dan rasulNya didustakan?" Telah menceritakan kepada kami 'Ubaidullah bin Musa, dari Ma'ruf bin Kharrabudz, dari Abu al-Thufail, dari 'Ali seperti itu. ${ }^{33}$

2) Asar yang diriwayatkan oleh Muslim dalam Kitab Muqaddimah.

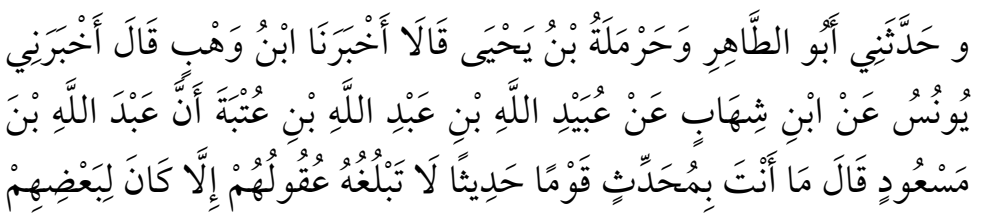

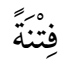

Dan, telah menceritakan kepadaku Abu al-Thahir dan Harmalah bin Yahya, telah mengabarkan kepada kami Ibnu Wahab, telah mengabarkan kepadaku Yunus, dari Ibnu Syihab, dari 'Ubaidillah bin 'Abdillah bin 'Utbah. 'Abdullah bin Mas'ud berkata, "Tidaklah kamu menyampaikan suatu perkataan yang tidak dimengerti oleh pikiran sekelompok orang, kecuali perkataan tersebut akan menimbulan fitnah bagi sebagian di antara mereka." ${ }^{34}$

Penentuan hadis yang berkaitan dengan prinsip penyampaian pelajaran sesuai kemampuan siswa dalam pendekatan SCL

${ }^{33}$ Abu Abdullah Muhammad bin Isma’il al-Bukhari, al-Jami‘ as-Ṣạ̣iḥ, Kitab "al-Tlm", No. 124, dalam Program Mausū'ah al-Hadis asy-Syarif, Versi 2 (t.tp.: Global Islamic Software Company, 1997).

${ }^{34}$ Abu al-Husain Muslim bin al-Hajjaj al-Qusyairi an-Naisyaburi, Șạ̣ị̣ Muslim, Kitab "Muqaddimah", dalam Program Mausū'ah al-Hạ̄is asy-Syarif, Versi 2 (t.tp.: Global Islamic Software Company, 1997). 
dalam artikel ini tidak dilakukan melalui penelusuran lewat kitabkitab kamus hadis semisal al-Mu'jam al-Mufabras li Alfazal-Hadis al-Nabawiy atau Miftạh Kunūz al-Sunnah karya A.J. Wensinck. Hal ini penulis lakukan karena sulitnya menentukan kata kunci untuk mengidentifikasi prinsip penyampaian pelajaran sesuai kemampuan siswa dalam hadis Nabi. Akhirnya, penelusuran terhadap hadis-hadis tersebut penulis lakukan secara random dengan bantuan dua buah buku yang menjelaskan berbagai macam metode pengajaran Rasulullah saw. Kedua buku tersebut adalah Begini Seharusnya Menjadi Guru: Panduan Lengkap Metodologi Pengajaran Cara Rasulullah saw. ${ }^{35}$ karya Fu'ad bin Abdul Aziz asy-Syalhub dan 40 Metode Pendidikan dan Pengajaran Rasulullab saw. ${ }^{36}$ karya 'Abdul Fattah Abu Ghuddah. Hasilnya adalah satu buah hadis dan dua buah asar sebagaimana yang telah penulis kemukakan di atas.

Berdasarkan penelusuran terhadap al-Kutub al-Tis'ah,, terdapat kurang lebih sebelas hadis, termasuk hadis riwayat $\mathrm{Abu}$ Dawud dalam Kitab "al-Adab" No. 4202, yang mengandung ide dasar prinsip penyampaian pelajaran sesuai kemampuan siswa dalam pendekatan SCL. Berikut ini uraiannya.

a. Hadis riwayat Imam Bukhari dalam Jami' al-Sạ̧ih, Kitab "al-Tlm", No. 124;

b. Hadis riwayat Imam Bukhari dalam Jami' al-Ṣậih, Kitab "al-Tlm", No. 125;

${ }^{35}$ Buku ini merupakan terjemah dari kitab al-Mu'allim al-Awwal: Qudwah li Kulli Mu'allim wa Mu'allimah. Fu'ad bin Abdul Aziz asy-Syalhub, Begini Seharusnya Menjadi Guru: Panduan Lengkap Metodologi Pengajaran Cara Rasulullah saw., terj. Jamaluddin (Jakarta: Darul Haq, 2010).

${ }^{36}$ Buku ini merupakan terjemah dari kitab ar-Rasülal-Mu'allim wa Asălibuhù fi at-TaTim. 'Abdul Fattah Abu Ghuddah, 40 Metode Pendidikan dan Pengajaran Rasulullah saw., terj. Mochtar Zoerni (Bandung: Irsyad Baitus Salam, 2009).

${ }^{37}$ Dalam menelusuri hadis-hadis tentang prinsip penyampaian pelajaran sesuai kemampuan siswa dalam pendekatan SCL, penulis menggunakan Program Mausü'ah al-Hadis asy-Syarif, Versi 2 (t.tp.: Global Islamic Software Company, 1997). 
c. Hadis riwayat Imam Bukhari dalam Jami' al-Sạ̧̧ih, Kitab "al-Jihäd wa al-Sair", No. 2782;

d. Hadis riwayat Imam Bukhari dalam Jami“ al-Ṣậih, Kitab "al-Birr wa al-Silah wa al-Adab", No. 4623;

e. Hadis riwayat Imam Bukhari dalam Jami" al-Saḅih, Kitab "al-Birr wa al-Silah wa al-Adab", No. 4624;

f. Hadis riwayat Imam Muslim dalam Șậih Muslim, Kitab "al-Muqaddimah";

g. Hadis riwayat Imam Muslim dalam Sặi̧h Muslim, Kitab "al-Imān", No. 47;

h. Hadis riwayat Imam Ahmad bin Hanbal dalam al-Musnad li al-Imām Aḥmad bin Muḥammad bin Hanbal, Kitab "Musnad al-Mukässirin min as-Ṣaḅabab", No. 6451;

i. Hadis riwayat Imam Ahmad bin Hanbal dalam al-Musnad li al-Imam Aḅmad bin Muhammad bin Hanbal, Kitab "Musnad al-Mukässirin min as-Șahäbab", No. 6757;

j. Hadis riwayat Imam Ahmad bin Hanbal dalam al-Musnad li al-Imám Ahmad bin Muḥammad bin Hanbal, Kitab "al-Ans ar 'r', No. 20.441.

Dari sebelas hadis di atas yang ada kaitannya dengan prinsip penyampaian pelajaran sesuai kemampuan siswa, termasuk di dalamnya hadis riwayat Abu Dawud dalam Kitab "al-Adab" No. 4202, penulis mengelompokkannya ke dalam dua tema. Pertama, hadis-hadis yang mengandung prinsip dasar prinsip penyampaian pelajaran sesuai kemampuan siswa, yaitu hadishadis yang terdapat dalam Jami al-Ṣạ̧ih karya Imam Bukhari, Kitab "al-Tlm", No. 124; Șā̧ih Muslim, Kitab "al-Muqaddimab"; Sunan Ab̄i Dāwud karya Abu Dawud, Kitab "al-Adab”, No. 4202; dan al-Musnad li al-Imām Aḥmad bin Muhammad bin Hanbal, Kitab "al-Anșär", No. 20.441.

Dalam dua hadis dan dua asar ini, ada empat pernyataan penting yang terkait dengan prinsip penyampaian pelajaran sesuai kemampuan siswa, yaitu: 
a. 'Ali berkata, "Berbicaralah dengan manusia sesuai dengan kadar pemahaman mereka, apakah kalian ingin jika Allah dan rasul-Nya didustakan?"38

b. 'Abdullah bin Mas'ud berkata, "Tidaklah kamu menyampaikan suatu perkataan yang tidak dimengerti oleh pikiran sekelompok orang, kecuali perkataan tersebut akan menimbulan fitnah bagi sebagian di antara mereka." ${ }^{39}$

c. Rasulullah saw. bersabda, "Posisikan manusia sesuai dengan kedudukannya." 40

d. Rasulullah saw. bersabda, "Tidaklah Allah mengutus seorang nabi kecuali dengan memakai bahasa pengantar yang dipahami oleh kaumnya." 41

Dua asar di atas menegaskan bahwa seorang dai, seorang pendidik, atau siapapun hendaklah berbicara kepada orang lain sesuai dengan bahasa, kemampuan, daya nalar, serta situasi dan kondisi yang dihadapinya. Jika tidak memerhatikan hal tersebut, dikhawatirkan isi pembicaran yang disampaikan akan menjadi fitnah dan sumber kekacauan, walaupun isi pembicaraan tersebut mengandung nilai-nilai kebaikan. Kedua asar ini dipertegas oleh sabda Rasulullah saw. dalam hadis riwayat Abu Dawud yang berisi perintah agar memosisikan manusia sesuai dengan kedudukan dan kemampuannya. Di samping itu, kedua asar ini juga ditegaskan oleh sabda Rasulullah saw. dalam hadis riwayat

${ }^{38}$ Abu Abdullah Muhammad bin Isma'il al-Bukhari, al-Jami' as-Saḥịh, Kitab "al-Ilm", No. 124, dalam Program Mausü'ah al-Hadis asy-Syarif, Versi 2 (t.tp.: Global Islamic Software Company, 1997).

${ }^{39}$ Abu al-Husain Muslim bin al-Hajjaj al-Qusyairi an-Naisyaburi, Șaḥiḥ Muslim, Kitab “Muqaddimah”, dalam Program Mausū'ah al-Hadis asy-Syarif, Versi 2 (t.tp.: Global Islamic Software Company, 1997).

${ }^{40}$ Abu Dawud Sulaiman bin al-Asy'ats as-Sijistani al-Asadi, Sunan Abi Dánud, Kitab "al-Adab”, No. 4202, dalam Program Mausūah al-Hạ̄is asy-Syarif, Versi 2 (t.tp.: Global Islamic Software Company, 1997).

${ }^{41}$ Ahmad bin Hanbal, Musnad Aḥmad bin Hanbal, Kitab "al-Anșar", No. 20.441, dalam Program Mausūah al-Hąäis asy-Syarif, Versi 2 (t.tp.: Global Islamic Software Company, 1997). 
Ahmad bin Hanbal. Dalam hadis ini, Rasulullah saw. menegaskan bahwa semua nabi dan rasul diutus oleh Allah swt. dengan bahasa pengantar yang dipahami oleh kaumnya. Dalam pandangan penulis, penegasan Rasulullah saw. dalam hadis ini tidak hanya sekadar bahasa, tetapi lebih luas dari sekadar bahasa. Yakni, mencakup pula daya nalar serta situasi dan kondisi umat yang dihadapinya. Menurut hemat penulis, inilah nilai-nilai dasar dari prinsip penyampaian pelajaran sesuai kemampuan siswa dalam pendekatan SCL yang sudah dipancangkan oleh Rasulullah saw. dan para sahabat sejak berabad-abad yang lalu.

Kedua, hadis-hadis yang menggambarkan praktik pengajaran Rasulullah saw. terhadap para sahabat dengan menggunakan prinsip penyampaian pelajaran sesuai kemampuan siswa. Dalam kelompok ini, ada tiga kisah yang menjadi contoh pembelajaran berbasis SCL yang dipraktikkan oleh Rasulullah saw., khususnya yang berkaitan dengan prinsip penyampaian pelajaran sesuai kemampuan siswa.

Contoh pertama adalah kisah Rasulullah saw. bersama Mu'adz bin Jabal. Hal ini terdapat dalam hadis yang diriwayatkan oleh Imam Bukhari, Kitab "al-'Tlm”, No. 125 dan hadis riwayat Imam Muslim, Kitab "al-Imān", No. 47. Dalam dua hadis ini diceritakan bahwa Rasulullah saw. bersabda kepada Mu'adz bin Jabal, "Tidak seorang pun hamba yang bersaksi dengan sungguhsungguh dari lubuk hatinya bahwa tidak ada tuhan selain Allah swt. dan Muhammad saw. adalah hamba dan rasul-Nya, kecuali Allah akan mengharamkan hamba tersebut masuk neraka." Namun, Rasulullah saw. melarang Mu'adz bin Jabal menginformasikan sabda ini kepada semua orang. Sebab, Rasulullah saw. khawatir jika informasi ini didengar oleh orang-orang, maka mereka akan enggan melakukan kebaikan.

Contoh kedua terdapat dalam hadis riwayat Imam Bukhari, Kitab "al-Jihäd wa al-Sair", No. 2782; hadis riwayat Imam Bukhari, Kitab "al-Birr wa al-Silah wa al-Adab", No. 4623; dan hadis riwayat Imam Bukhari, Kitab "al-Birr wa al-Silah wa al-Adab”, No. 4624. 
Dalam tiga hadis ini diceritakan bahwa seseorang mendatangi Rasulullah saw. agar diizinkan ikut berjihad dan ikut berhijrah bersama Rasulullah saw. agar mendapat pahala dari Allah swt. Namun, tidak sebagaimana Rasulullah saw. mengizinkan sahabat lainnya untuk ikut berjihad dan berhijrah bersamanya, terhadap orang ini Rasulullah saw. malah bertanya, "Apakah kedua orang tuamu masih hidup?" Orang ini menjawab, "Masih." Lantas Rasulullah saw. bersabda, "Kalau begitu, pulanglah kepada kedua orang tuamu dan berbaktilah kepada keduanya dengan baik." Sebab, di balik bakti terhadap orang tua terkandung kemuliaan yang sebanding dengan pahala jihad.

Contoh ketiga terdapat dalam hadis yang diriwayatkan oleh Ahmad bin Hanbal, Kitab "Musnad al-Mukässirin min as-Ṣạ̣. abab", No. 6451 dan hadis riwayat Ahmad bin Hanbal, Kitab "Musnad al-Mukässirin min as-Ṣaḥabab", No. 6757. Dalam hadis ini dikisahkan ada dua orang, yakni seorang pemuda dan orang tua, yang mendatangi Rasulullah saw. dan bertanya dengan pertanyaan yang sama, "Wahai Rasulullah, bolehkan aku mencium istriku ketika aku sedang berpuasa?" Kepada pemuda, Rasulullah saw. menjawab, “Tidak boleh!” Sementara, kepada orang tua, Rasulullah saw. menjawab, "Ya, boleh.” Mendengar dua jawaban yang bertentangan ini, para sahabat heran. Lantas Rasulullah saw. menjelaskan, "Ketahuilah, sesungguhnya orang tua itu lebih dapat mengekang hawa nafsunya daripada pemuda."

Tiga kisah ini menahbiskan satu pesan penting bahwa tidak semua orang berhak mendapatkan informasi, pelajaran, serta kewajiban yang sama. Hal ini didasarkan pada situasi dan kondisi, kemampuan dan kesanggupan, serta daya nalar seseorang. Dengan demikian, penulis menggarisbawahi satu poin penting bahwa dalam memberikan pengajaran kepada para sahabatnya, Rasulullah saw. bertumpu pada situasi dan kondisi mereka. Dan, inilah sejatinya contoh praktis dari pendekatan SCL dengan memakai prinsip penyampaian pelajaran sesuai kemampuan siswa dalam pembelajaran. 
Sepuluh hadis di atas sama sekali tidak bertentangan dengan hadis riwayat Abu Dawud dalam Kitab "al-Adab" No. 4202 tentang prinsip penyampaian pelajaran sesuai kemampuan siswa. Justru hadis-hadis ini menjadi penguat terhadap hadis riwayat Abu Daud yang berkualitas da îif. Jika hadis riwayat Abu Dawud tersebut berisi penegasan dan perintah dari Rasulullah saw. agar menempatkan manusia sesuai dengan situasi dan kondisinya, maka sepuluh hadis lainnya menjelaskan perintah dan contoh praktis dari Rasulullah saw. agar berbicara kepada manusia sesuai dengan situasi, kondisi, dan daya nalar mereka. Dengan demikian, sebelas hadis di atas berada dalam satu kesatuan tematis komprehensif, yakni berkaitan dengan prinsip pembelajaran yang memerhatikan situasi dan kondisi peserta didik atau pembelajaran berbasis SCL.

\section{Simpulan}

Berdasarkan penelusuran terhadap ayat Al-Qur'an dan hadis Nabi yang bisa dijadikan pijakan teologis-normatif bagi pengembangan pembelajaran dengan menggunakan prinsip penyampaian pelajaran sesuai kemampuan siswa dalam pendekatan SCL, berikut ini beberapa hal yang dapat disimpulkan.

Pertama, perubahan arah pembelajaran dari pembelajaran berpusat pada guru SCL menjadi pembelajaran berpusat pada siswa SCL dipicu oleh perubahan paradigma pembelajaran dari paradigma positivistik menjadi paradigma konstruktivistik. Perubahan ini disebabkan oleh perkembangan zaman yang ditandai dengan percepatan pertumbuhan teknologi dan percepatan arus informasi yang meniscayakan adanya perubahan di segala bidang, termasuk di dunia pendidikan. Paradigma positivistik berupaya mengubah arah pendulum paradigma positivistik yang mengkondisikan pembelajaran dengan pendekatan yang bersifat memaksa sehingga menciptakan suasana pembelajaran yang tidak nyaman, menimbulkan rasa takut, dan bahkan bisa membuat siswa stres, menjadi pembelajaran dengan suasana yang lebih kondusif 
dan menyenangkan. Paradigma baru pembelajaran ini berhasil menginspirasi para praktisi pendidikan, sehingga bermunculanlah teori-teori baru pembelajaran yang lebih menghargai siswa sebagai subjek pendidikan sekaligus sebagai manusia seutuhnya.

Kedua, pendekatan pembelajaran yang berpusat pada siswa SCL muncul untuk merespons perubahan paradigma di atas. Dalam SCL, fungsi guru tidak lagi mengajar secara langsung sebagaimana yang biasa dipertontonkan di kelas-kelas konvensional, tetapi guru lebih berfungsi untuk memfasilitasi dan membimbing siswa dalam melakukan pembelajaran mandiri. Dalam strategi pembelajaran yang berpusat pada siswa, guru secara sadar menempatkan perhatiannya lebih banyak pada keterlibatan, inisiatif, dan interaksi sosial siswa di kelas. Dengan adanya perubahan paradigma pendidikan dari pengajaran yang berpusat pada guru (teacher-centered learning atau lecture-centered learning) menjadi pembelajaran yang berpusat pada siswa SCL diharapkan proses pembelajaran akan lebih efektif dalam mewujudkan pendidikan yang demokratis, berkeadilan, tidak diskriminatif, dan menjunjung tinggi nilai-nilai hak asasi manusia, nilai-nilai agama, nilai-nilai budaya, serta kemajemukan bangsa.

Ketiga, dengan menggunakan kategorisasi tiga istilah kunci, yaitu عَدَرَبِّيُّ , ditemukan 21 ayat Al-Qur'an yang mengandung ide dasar prinsip penyampaian pelajaran sesuai kemampuan siswa dalam pendekatan SCL. Semua ayat Al-Qur'an ini ingin menegaskan poin penting, yakni keharusan untuk menempatkan manusia sesuai dengan kedudukan dan kemampuannya serta berbicara dengan mereka sesuai dengan situasi, kondisi, dan kemampuan daya nalar mereka.

Keempat, ada sekitar 11 hadis yang secara tersirat ataupun tersurat mengandung prinsip penyampaian pelajaran sesuai kemampuan siswa dalam pendekatan SCL. Hadis-hadis ini tersebar dalam beberapa kitab hadis yang diriwayatkan oleh Imam Bukhari, Imam Muslim, Abu Dawud, dan Ahmad bin Hanbal. Sebelas hadis ini terbagi ke dalam dua kelompok, yaitu: (1) hadis 
yang mengandung ide dasar prinsip penyampaian pelajaran sesuai kemampuan siswa dan (2) hadis yang menggambarkan praktik pengajaran Rasulullah saw. terhadap para sahabat dengan menggunakan pendekatan SCL, khususnya yang berkaitan dengan prinsip penyampaian pelajaran sesuai kemampuan siswa. [] 


\section{DAFTAR PUSTAKA}

al-Asadi, Abu Dawud Sulaiman bin al-Asy'ats as-Sijistani, Sunan

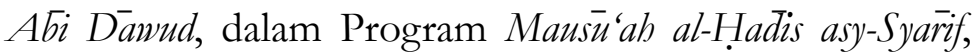
Versi 2, t.tp.: Global Islamic Software Company, 1997.

al-Baqi, Muhammad Fu'ad Abd, al-Mu'jam al-Mufahras li Alfăa AlQurāan Al-Käim, Kairo: Dār al-Hadìis, 2007.

al-Bukhari, Abu Abdullah Muhammad bin Isma'il, al-Jami' aș-Sạ̣. iḥ, dalam Program Mausū'ah al-Hǟis asy-Syarif, Versi 2, t.tp.: Global Islamic Software Company, 1997.

Dananjaya, Utomo, Media Pembelajaran Aktif, Bandung: Penerbit Nuansa bekerja sama dengan Institute for Education Reform [IER] Universitas Paramadina, 2010.

Ghuddah, 'Abdul Fattah Abu, 40 Metode Pendidikan dan Pengajaran Rasulullah saw., terj. Mochtar Zoerni, Bandung: Irsyad Baitus Salam, 2009.

Hadi, Rahmini, "Dari Teacher-Centered Learning ke SCL: Perubahan Metode Pembelajaran di Perguruan Tinggi", dalam Jurnal Insania, Vol. 12, No. 3, September-Desember 2007.

Hamruni, Edutainment dalam Pendidikan Islam dan Teori-teori Pembelajaran Quantum, Yogyakarta: Fakultas Tarbiyah UIN Sunan Kalijaga Yogyakarta, 2009.

Hanbal, Ahmad bin, Musnad Aḥmad bin Hanbal, dalam Program Mausü'ah al-Hadis asy-Syarif, Versi 2, t.tp.: Global Islamic Software Company, 1997.

Kementerian Agama RI, Al-Qur'an Tajwid dan Terjemahnya Syāmil Al-Qur'an, Bandung: Sygma Examedia Arkanleema, 2010.

Marjohan, School Healing: Menyembubkan Problem Sekolah, Yogyakarta: Insan Madani, 2009. 
an-Naisyaburi, Abu al-Husain Muslim bin al-Hajjaj al-Qusyairi, Șaḥiḥ Muslim, dalam Program Mausū'ah al-Had̄is asy-Syarif, Versi 2, t.tp.: Global Islamic Software Company, 1997.

Nata, Abuddin, Perspektif Islam Tentang Strategi Pembelajaran, Jakarta: Kencana, 2009.

Nugraheni, Endang, "Student Centered Learning dan Implikasinya terhadap Proses Pembelajaran", dalam Jurnal Pendidikan, Volume 8, Nomor 1, Maret 2007.

Peraturan Pemerintah Republik Indonesia No. 19 Tahun 2005 Tentang Standar Nasional Pendidikan.

Riyanto, Yatim, Paradigma Baru Pembelajaran: Sebagai Referensi bagi Pendidik dalam Implementasi Pembelajaran yang Efektif dan Berkualitas, Jakarta: Kencana, 2010.

Sanjaya, Wina, Strategi Pembelajaran Berorientasi Standar Proses Pendidikan, Jakarta: Kencana, 2010.

asy-Syalhub, Fu'ad bin Abdul Aziz, Begini Seharusnya Menjadi Guru: Panduan Lengkap Metodologi Pengajaran Cara Rasulullah saw., terj. Jamaluddin, Jakarta: Darul Haq, 2010.

Undang-undang No. 20 Tahun 2003 Tentang Sistem Pendidikan Nasional. 
